\title{
Confirmatory factor analysis of the teaching strategy for HOTs and LOTs Inventory in the Malaysian context
}

\author{
Nor Hasnida Che Md Ghazali*, Nurulhuda Md Hassan, Norfishah Mat Rabi \& \\ Syaza Hazwani Zaini \\ Sultan Idris Education University, Malaysia
}

Received: 20 March 2018; Accepted: 1 September 2018; Published: 1 December 2018

\begin{abstract}
Promoting students' higher order thinking skills is now becoming more important in an education system. An effective teaching strategies are required to teach those skills to students. Hence, a valid, reliable and practical instrument is needed to evaluate teaching strategies used in promoting students' higher order thinking skills (HOTs) and lower order thinking skills (LOTs). The aim of this study is to explore different factor structure of the teaching strategies scale by using the secondorder Confirmatory Factor Analysis. The instrument is adapted from an instrument developed by Gulistan (2016) to suit with the Islamic education teachers in the Malaysian context. 220 primary school teachers teaching Islamic education subject was selected randomly from one of the state in Malaysia. The content validity is assessed by a group of experts, and the construct validity is measured by Confirmatory Factor Analysis. The reliability of the instrument is measured by the alpha coefficient reliability or Cronbach Alpha. Results indicated that the teaching strategies inventory is a valid and reliable scale. The measurement model is validated with two factors ('Acquiring Knowledge' and 'Applying Knowledge and Reflection on Knowledge'). This study provides support for using a valid instrument in evaluating teaching strategies used by Islamic education teachers in primary level in real study later.
\end{abstract}

Keywords: Teaching strategies, HOTs, LOTs, confirmatory factor analysis.

\section{Introduction}

Globalisation and internationalisation are the two challenges that demand a dynamic transformation in the education system in Malaysia (Ganapathy \& Kaur, 2014). Besides fulfilling the 21st century global needs, responding to such challenges is also important to ensure the achievement of advanced nation status by 2020. This notion is supported by Nooraini and Khairul Azmi (2014) who claimed that the development of thinking skills among students has been among the objectives of education system in order to help Malaysia in achieving Vision 2020. The transformation in the education system in Malaysia is manifested in the National Education Blueprint (2013-2015) whereby articulation of the specific skills and attributes including HOTs has been refined. Such refinement is vital as a preparation in producing knowledgeable students with real life skills so that they can compete in the global labor market. In other words, the new reform in learning systems emphasizes the importance of cultivating students' higher level thinking abilities (Kim, 2005).

Higher order thinking skills (HOTs) refer to the ability to apply knowledge and solve problems in a creative and innovative way, in which such ability lead to the creation of a new dimension based on the knowledge that has been learnt (Ministry of Education, 2013). It aims at producing knowledgeable students who can think critically and creatively. Such thinking, which implies students' skills in terms of application, analysis and evaluation of knowledge in and outside the classroom is vital in enabling them to compete successfully in the global world (Ganapathy \& Kaur, 2014). In Malaysia, the elements of HOTs have been introduced to pursue the continuation of critical and creative thinking skills. HOTs become the focus in the transformation of the education curriculum in the Malaysia Education Development Plan (PPPM) 2013-2025. Forehand (2010)

\footnotetext{
*Email: hasnida@fpm.upsi.edu.my
} 
stated that the concept of HOTs is derived from the Bloom's Taxonomy introduced in 1956 involving knowledge and the development of intellectual skills. Bloom's Taxonomy of Cognitive Domain listed six major categories of cognitive processes which are hierarchically ordered from concrete to abstract (Pappas et al., 2012). Such thinking, from the simplest to the most complex, are knowledge, comprehension, application, analysis, synthesis and evaluation (Clark, 2010; Yahya, Toukal, \& Osman, 2012). Knowledge, comprehension and application are regarded as lower order thinking skills (LOTs) since they require basic recognition or recall (Clark, 2010) while analysis, synthesis and evaluation are regarded as HOTs and are believed to promote students' learning performance (Forehand, 2010).

\section{Literature Review}

Teachers should change their traditional teaching methods to more contemporary teaching practices which incorporate HOTs (Ganapathy \& Kaur, 2014). In other words, teachers need to design various pedagogical activities that stimulate and encourage students to develop their thinking skills. Besides that, the transformation also demand the change in teachers' assessment practices which traditionally focusing on a series of past year questions and drilling for content recall by including questions which require students to think critically, creatively and innovatively in diverse settings (Ganapathy $\&$ Kaur, 2014). Thinking skills are at the heart of learning in that they make certain learning possible, and make possible the acts of carrying out certain tasks (Passey, 2000). It is possible to consider learning without thinking (learning by rote or learning by accident), as well as learning with thinking, of course. The role of memorization is clearly important here, since memorization plays a different role in the case of learning without thinking to that which it does in the case of learning with thinking. Internalization of information can occur in the same ways in both cases, but internal processing in the case of learning without thinking relies vitally upon memorization, while in the case of learning with thinking memorization is only a part of the wider internal processing of thinking and learning. Islamic education curriculum for primary school level in the Malaysian context is a curriculum which includes Al-Quran, Hadith, Faith, Worship, History, Islamic civilization, Morality and Jawi language (JNJK, 2015). And, this study will be focusing on all of the aspects, and not on worship or faith only. In addition, the objective of teaching Islamic education subject in primary schools is to produce knowledgeable individuals, devout, willing to do good deeds and noble by making the Quran and as-Sunnah as a guide in life to be a servant of God who is successful in this world and the hereafter (JNJK, 2015). This objective is quite tremendous so it needs a tremendous effort as well in order to achieve it.

Fundamental to success of an education system lies in the quality of the National Curriculum, thereby determining the desired human capital quality (BPK, 2014). Thus, the priority by the ministry now is to build a curriculum that meets international standards with the emphasis on creative skills, problem solving and innovation. A current study conducted in Putrajaya on 20 teachers who are teaching Islamic education subject showed that the implementation of HOTs in management and administration, understanding of HOTs in teaching and learning process and teaching strategies concerning HOTs are at a moderate level, whereas the planning of HOTs in teaching and learning process, construction of HOTs items and the evaluation of HOTs are at a high level (Norasmahani et. al., 2015). Another recent study conducted in Selangor concerning Islamic education teachers in primary schools showed that the level of knowledge and skills in embedding HOTs in teaching and learning process are at a high level (Wan Ismail et al., 2016). However, to date there is no study being done to determine its relationship with students' academic performance in Islamic education, especially when it comes to performance regarding test with HOTs items. A study by Nazimah (2013) determines the achievement in Jawi skills for two groups of students with different teaching and learning method. Students taught with a Jawi skill learning module with HOTs elements achieve better than those taught with recent school-based assessment system.

According to King et al. (2000), specific methods and strategies to enhance HOTs are established with the student-centered classroom incorporating thinking skills into lesson by using instructional communications, scaffolding, incorporating learning and thinking strategies, using 
various questioning strategies, the use of feedback, team activities (students discussion, peer tutoring or cooperative learning) or computer-mediation. Furthermore, numerous studies have shown that higher level questions lead to higher cognitive processes (Batson, 1981). In other words, it has been claimed that the level of teachers' questions asked is directly proportional to the level of students' thinking (Şeker, \& Kömür, 2008). However, a study conducted by Wan Mat and Norkhairiah (2011) showed that types of questions used by the Islamic education teachers in classroom are low level of questioning. Next, HOTs could be measured using multiple-choice items, multiple-choice items with written justification, constructed response items, performance tests or portfolios (King et al., 2000). These methods can be used in both, classroom or state wide assessments. However, studies suggested that teacher assessment of HOTs is rare and most of the items are knowledge items (referring to Bloom taxonomy) and not many items measure skills from the three upper skills of Bloom taxonomy which are analysis, synthesis or evaluation (Stiggins et al., 1989). The positive impact of HOTs on students' learning has been found in numerous studies, including the project that has been conducted by the National Research Council (1987) involving several American schools. Such project revealed that HOT learning process enabled students to experience long term memory compared to LOT learning process. Specifically, HOT learning process in such project involved the teaching of content information by using real-life contexts as a means to cultivate the use of critical thinking skills. Apart from that, teachers were required to vary their teaching methods according to the need of the skill. Besides encouraging the application of the knowledge gained, such practices also facilitates the process of internalizing the abstract conceptual implication through the exposure of various contextual settings. HOTs are believed to be effective not only in promoting the generation of new knowledge and skills, but such skills are regarded as suitable to be adapted to everyday life which evolves over time (Forster, 2004; Tan et al., 2006). Besides that, such skill are also vital in fostering lifelong learning and believed to provide enormous benefits to the country in the future (MOE, 2012). Due to those reasons, Ministry of Education asserted that HOTs have to be implemented in the Malaysian education system.

The National Research Council (1987) has recommended that approaches that should be employed in the teaching of content information must support the development of HOTs including inferring, analyzing, and problem solving. Besides, it has suggested that teachers consider the inclusion of new and authentic problems in their assessment and classroom practices in order to encourage the application of HOTs among students. Gulistan et al. (2015) asserted that the provision of authentic problems activates HOTs since students need to encounter unfamiliar problems, uncertainties, questions or dilemmas. With regard to classroom practices, Yee et al. (2012) suggested that the attainment of HOTs can be achieved either through conventional teaching and learning environment or in an individualized learning. The implementation of HOTs should be done holistically regardless of students' cultural background as findings from research conducted by Newman, Bryk and Nagaokan (2001) revealed that students from diverse ethnic and socio-economic background should be given the opportunity to develop their HOTs in authentic classroom teachings. The success of the implementation of HOTs in education also depends on the teaching and learning practices undertaken by teachers. According to Nelson and Sassi (2000), such practices depends on the knowledge of pedagogy possessed by teachers. Thus, teachers need to have pedagogical knowledge in order to implement the curriculum successfully. The level of pedagogical knowledge possessed by teachers also serves as an indicator in determining teachers' level of competency (Anuar \& Nelson, 2015). In this sense, Rosma et al. (2012) assert that all teachers should understand the pedagogical content knowledge on the implementation of HOTs and thus, apply it in their teaching and learning practices.

Teachers' knowledge of pedagogy is also crucial in the development of procedural skills that can be applied to challenge and encourage students' ideas (Anthony \& Walshaw, 2009). In other words, the deeper the teachers' knowledge of pedagogy, the better the procedural skills that they will apply to foster students' HOTs. The knowledge of pedagogical content is useful in facilitating the development and expansion of the level of understanding on the basic knowledge of a discipline (Bales \& Saffold, 2011). In this regard, Abdullah et al. (2017) claimed that teachers should apply suitable and effective pedagogy which promotes the development of critical, creative, and innovative 
thinking among students. This requires teachers to be able to reflect on their teaching to determine the most effective teaching strategies and techniques in order to ensure the achievement of learning objectives (Murray, 2011). Besides, teachers are also required to shift their practices from the sole dependence on textbooks to the learning of diverse teaching strategies that can help in optimizing students' thinking (Jonathan et al., 2013). The theory of constructivism, which emphasizes the importance of students' knowledge construction through the association between prior and new knowledge, can the basis in the selection of appropriate pedagogies to teach HOT skills (Nurazilawati et al., 2013). In Malaysia, the principles of HOTs has been stressed in the teaching and learning practices as outlined in the standard curriculum documents (Abdullah et al., 2017). The implementation of HOTs in teaching and learning practices is a complex process. A study conducted by Caroline and Abdul Said (2014) confirmed that one of the major obstacles that thwarts the practice of HOTS in lesson was teachers' lack of HOTs knowledge. This notion is supported by enormous studies which found that most teachers do not possess sufficient of HOTS knowledge and its application in teaching and learning processes (Veenman et al., 2006; Ben-David \& Orion, 2012; Seraphin et al., 2012), thus remarks a serious gap between research-based recommendations and the actual state of teachers' HOTs knowledge (Zohar \& Banzilai, 2015). This problem needs to be addressed seriously due to the great impact that HOTS knowledge has towards teachers' teaching practices (Georghiades, 2004; Thomas, 2012). Caroline and Abdul Said (2014) argued that the possession of HOTs knowledge is crucial in helping teachers in the selection of teaching methods that suit students' needs. This statement is supported by Cope (2014) who claim that knowledge of HOTs enables teachers to nurture the habit of thinking among students and gives them ideas on how to provide opportunities for students to challenge their abilities which eventually result in the development of HOTs among students. In order to improve teachers' pedagogical knowledge, Abdullah et al. (2017) recommended teachers to increase their participation in HOTs courses.

In order to gain pedagogical knowledge of HOTs, teachers can refer to Frangenheim's model (2006) as it promotes strategies for pedagogical practices by integrating HOTs. This model stresses the importance of using Thinking Skills Framework in fostering HOTs since it leads to the generation of creative and innovative ideas among students. Besides providing a clear understanding about the importance of using HOTs, this model also provides teachers with various creative and innovative strategies that can be employed in their classroom practices. The application of such strategies is aimed at increasing students' engagement in learning and encouraging the practice of HOTs in effective ways through students' involvement in various activities. One of the strategy which could foster HOTs amongst students is effective questioning techniques. According to Supramani (2006), effective questioning techniques is one of the methods that can be employed to enhance students' thinking skills. This is due to the fact that students will build the knowledge of problem solving strategies as well as find the justification for every solution when being questioned the HOT skills questions (Adam, 2011). Another strategy that can be used to enhance students' HOTs is metacognitive training and instruction. According to Zohar and Banzilai (2015), such strategy has been proven to be effective in improving students' performance in diverse fields. Specifically, knowledge of tasks and strategies, which are among the components in metacognition, are crucial in teaching HOTs among students (Zohar \& Banzilai, 2015). Besides that, such knowledge is also need to be combined with metacognitive skills such as planning, monitoring, and evaluating in order to ensure that HOTs strategies are executed successfully. In other words, the terms metacognition and HOTs can be used interchangeably as suggested by Zohar (2008).

A number of metacognitive instructional strategies can be used to foster HOTs among students (Zohar and Banzilai, 2015). The first strategy is metacognitive prompts, which entails the use of metacognitive cues, questions, or checklists that students were asked to use during learning activities such as problem solving and inquiry learning. According to Zohar and Banzilai (2015), such prompts serve as a reminder for students to employ metacognitive skills while engaging in learning activities and as a scaffold in group discussion and written assignments. Besides, metacognitive prompts can also be used to activate students' metacognitive knowledge regarding HOT strategies (Fund, 2007; Peters \& Kitsantas, 2010). The second strategy is explicit instruction, which involves explicit practices to teach metacognitive knowledge and metacognitive skills. Teachers' explanations and demonstrations of HOTS are among forms of explicit instruction in HOT 
studies (Duncan \& Arthurs, 2012). Besides that, explicit instruction can also be done by engaging students in knowledge construction activities through which students are required to build their metacognitive understandings of HOT (Kaberman \& Dori, 2009). Apart from that, explicit instruction also involves the use of appropriate teaching materials to foster students' understanding of HOTS. In this regard, Zohar and Banzilai (2015) suggest that teachers need to use learning materials that offer models and explanations regarding HOT in order to build such understanding among students. The third strategy is practice and training, which implies the importance of asking students to apply and practice what they learned during problem solving activities. According to Zohar and Banzilai (2015), such strategy can support the activation and application of metacognitive knowledge and skills among students. Such activation and application are believed to happen not only over prolonged periods of time, but also in multiple problem solving contexts. The fourth strategy is metacognitive discussion, through which students are encouraged to articulate the cognitive and metacognitive processes that they apply during HOT discussions. According to Zohar and Banzilai (2015), such discussions can be done in two ways, which are whole class and group discussions. Through whole class discussions, students' development of understandings of their thinking is supported when teachers directly talk with their students about their thinking to make it visible (Wu \& Pedersen, 2011). In group discussions, the structure of the discussion has been planned carefully and intentionally to provide students with opportunities to engage in metacognitive talk among them and cues and prompts will be used as scaffolds that evoke cognitive and metacognitive processes (Peters \& Kitsantas, 2010).

There are several characteristics which determine the effectiveness of teaching strategies for developing students' HOTs (Chapman \& Aspin, 2013). Firstly, activating the student's prior knowledge. This step is important because it helps students to make connections to the new information they will be learning. By tapping into what students already know, teachers can assist students with the learning process. Secondly, is to use classroom activities to provide students with information, straightforward steps, and gives them the opportunity for hands-on inquiry for students seeking inspiration. Many of these activities can be prepared and completed in a short time, making them easy to integrate into a classroom setting. Third is grouping approach whereby students share experiences in small group activities. This will improve students' knowledge and help them to apply the acquired knowledge into real life situations. Lastly is the assessment forms. Teachers could use different form of assessment such as alternative assessment and evaluation approaches to assess students' HOTs. There is a research conducted by Shukla and Dungsungnoen (2016) on teaching strategies. They found out that students have shown medium level of higher order thinking skills. The teachers are using more knowledge development and application strategies. The teachers' professional components such as designation, teaching experience and qualification are significantly correlated with strategies used for imparting HOTs.

\section{Statement of the Problem}

According to Noraishah (2004), teaching is not systematic and there is no continuity between current and previous lessons which leads to students could not afford to use HOTs. It is found that Islamic Education Excellent Teachers do not really apply teaching methods which could improve creative thinking such as brainstorming, estimating, managing mind map or projects although those are the ones that could boost critical thinking of students (Kamarul Azmi, 2010). Furthermore, students, from primary or secondary level are not interested with Islamic education subject, and this seems to be distressing especially for the curriculum developer (Tengku Sarina and Faridah, 2008). A study also found that students are not good in Jawi skills, hence they are having problem to answer questions on this in examinations (Nazimah, 2013). However, several studies have been conducted showing that teachers do have an awareness of the importance of HOTs in teaching and learning but they lack the knowledge and skills in applying HOTs in teaching and learning (Rajendran, 2016). This research is important since it validate an instrument with items suitable for Islamic education subject at a primary level. To date, no study has investigated the teaching strategies related to Islamic education subject. Recent study found that there is quite a lot of research been done concerning 
HOTs in science and mathematics subjects but, still not many research being done on HOTs implemented in Islamic education among primary school children (Wan Ismail et. al., 2016). Furthermore, the use of SEM also seems to be a very good approach compared to ordinary least square methods since SEM has the ability to gain a more efficient and accurate findings because it analyses the structure of mean, variance and covariance simultaneously and it is also more efficient in making estimation for multiple variables (Zainuddin, 2012).

\section{Research Objectives}

The purpose of this study is to assess the validity and reliability of an inventory for assessing teacher strategies in promoting students' HOTs and LOTs. Specifically, this study seeks to; i) establish the validity of the inventory; ii) establish the reliability of the inventory; and iii) investigate the strategies used in teaching.

\section{Methodology}

This study is both cross-sectional and survey in nature. It is cross-sectional in that it focuses on major variables (constructs) of lower school teaching and learning environment at a specific period. It is also a survey research design because the teacher and students were surveyed on key variables of teaching and learning. In this study, the population consists of school teachers working in the government primary schools teaching Islamic education subject in Malacca. Simple random sampling is used to choose primary schools all over Malacca, and then all the teachers in that chosen schools are treated as samples for this study. Teachers are the respondents of this study. The instrument used in this study is adapted from Gulistan et. al (2015). They have developed an inventory known as Strategies Used Survey Questionnaire (SUS-Q) to determine teaching strategies used by 7 th grade secondary science teachers in teaching science.

Originally, it consists of 34 items in the form of 5 -point Likert scale ( $1=$ never to $5=$ always $)$ based on the constructs of cognitive development. After it has gone through validity and reliability process, it leaves with 31 items only. The sample for their study was 2127 th grade science teachers in the Iraqi-Kurdistan region. Data were analyzed by adopting descriptive and inferential statistics such as t-test and one-way ANOVA. Findings of the study indicated that the most popular teaching strategy is the strategy for acquiring knowledge which focused more on memorizing basic concepts in science, while the least used teaching strategy is the strategy for applying knowledge such as problem solving and hands-on activities. Items in their instrument are organized into three main constructs with 31 items altogether; i) Strategies used for acquiring knowledge (14 items); ii) Strategies used for applying knowledge (8 items); and iii) Strategies used for reflection on knowledge (9 items).

i) Acquiring knowledge (item 1-14): It represented the strategies used by teachers to promote LOTs such as activating students' prior knowledge whereby students can then gather the information in order to understand the phenomena, by using basic thinking skills.

ii) Applying knowledge (items 15-22): It represented with promoting HOTs to enhance students' ability to apply knowledge. Teachers must encourage students to work with data or scientific material using different thinking skills to move to deep understanding of usefulness and applicability of this material to everyday life, by using integrated science process skills.

iii) Reflection on knowledge (items 23-31): This requires teacher to encourage students to use HOTs in order to analyze and make judgment about what has happened, which will increase students' reflective thinking.

Why this instrument is chosen? Firstly, it is an instrument to determine strategies used by science teachers to promote HOTs and LOTs in science education so, it is suitable with this study in determining teaching strategies concerning HOTs and LOTs in Islamic education subject. Secondly, this instrument is developed to suit the schools in Iraqi Kurdistan region which is not a developed 
country and still in the process of developing its HOTs. What changes have been done? Changes have been made by referring to the Curriculum and Assessment Standard Document for Islamic education subject for Year 4, 5 and 6 and also the Administration Guidelines for Islamic education subjects produced by the ministry in 2015 . Changes are made to suits the teaching of Islamic education subject at primary level.

\section{Findings and Discussion}

Results are based on the percentage of respondents' views on each item. The development of a measurement model is discussed. Pooled latent constructs or measurement model is formed. It is modeled as a second-order structure following the underlying theory, when there is a higher level factor which is considered accountable for the lower order factors (Byrne, 2010). In this study, the results of EFA reveal that the instrument scale yields two factors with 20 items instead of three factors with 31 items originally. Then, the reliability is checked (Table 1) followed by the AMOS Output (Table 2).

Table 1. Overall Cronbach Alpha Value for the Teaching Strategy Constructs

\begin{tabular}{lcccc}
\hline \multicolumn{1}{c}{ Construct } & $\begin{array}{c}\text { No of } \\
\text { items }\end{array}$ & Item & $\begin{array}{c}\text { Overall Cronbach } \\
\text { Alpha Value }\end{array}$ \\
\hline $\begin{array}{l}\text { Acquiring Knowledge (AK) } \\
\text { Applying and Reflection }\end{array}$ & on & 8 & b1, b2, b3, b4, b5, b11, b12, b13 & 0.841 \\
Knowledge (AR) & & & b17, b18, b20, b21, b22, b23, b24, & 0.933 \\
\end{tabular}

Table 2. AMOS Output for the hypothesized model for summary statistics

\begin{tabular}{lc}
\hline Computation of degrees of freedom number & \\
\hline Number of distinct sample moments & 210 \\
Number of distinct parameters to be estimated & 41 \\
Df & 169 \\
Result & \\
Chi-square & 1982.639 \\
Df & 169 \\
Probability level & 0.000 \\
\hline
\end{tabular}

In reviewing the goodness-of-fit statistics, it shows that $\mathrm{X}^{2} / \mathrm{df}=11.732, \mathrm{CFI}=0.634, \mathrm{IFI}=0.635$, $\mathrm{TLI}=0.588, \mathrm{GFI}=0.619$ and $\mathrm{RMSEA}=0.183$. This measurement model provided a poor fit. No items are deleted due to low factor loading value. Then, we look at the modification index values. Then, four items are deleted. Again, the model is still not fit with $\mathrm{X}^{2} / \mathrm{df}=9.172, \mathrm{CFI}=0.747, \mathrm{IFI}=0.748$, $\mathrm{TLI}=0.705, \mathrm{GFI}=0.729$ and RMSEA $=0.160$. 


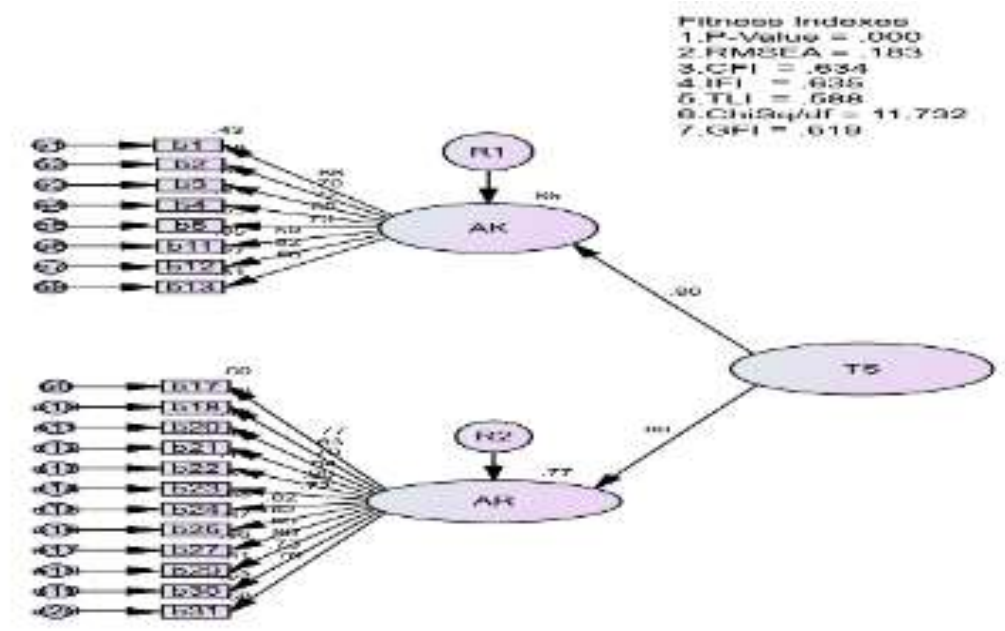

Figure 1. The measurement model

Then, after 13 items are deleted, it shows that $\mathrm{X}^{2} / \mathrm{df}=11.504, \mathrm{CFI}=0.907, \mathrm{IFI}=0.907, \mathrm{TLI}=0.849$, $\mathrm{GFI}=0.890$ and RMSEA $=0.181$. The model is fit.

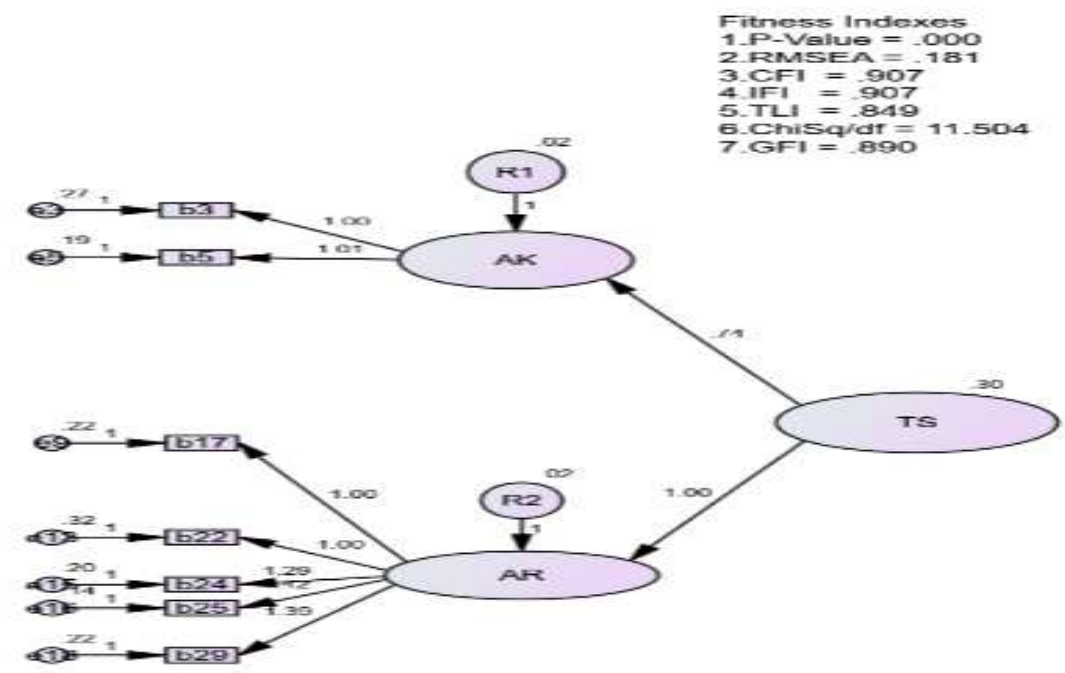

Figure 2. The Final Measurement Model

So, it is a two-factor model with 7 items. Byrne (2010) asserted that assessment of model adequacy should be based on theoretical, statistical and practical considerations. Looking at Table 3 , the value of skewness indicates that every item is approximately normally distributed. The value of kurtosis is also acceptable and the value of multivariate kurtosis which is lower than 50.0 indicated multivariate normality distribution of the data set. Finally, the issues of uni-dimensionality, validity and reliability are addressed in Table 4 .

Table 3. Assessment of normality

\begin{tabular}{lcccccc}
\hline \multicolumn{1}{c}{ Variable } & Min & Max & Skewness & c.r & kurtosis & c.r \\
\hline b29 & 1.000 & 5.000 & -0.795 & -5.804 & 1.261 & 4.603 \\
b17 & 1.000 & 5.000 & -0.953 & -6.957 & 1.947 & 7.111 \\
\hline
\end{tabular}




\begin{tabular}{lllllll}
\hline b22 & 1.000 & 5.000 & -0.627 & -4.576 & 0.338 & 1.235 \\
b24 & 1.000 & 5.000 & -0.469 & -3.423 & 1.104 & 4.033 \\
b25 & 1.000 & 5.000 & -0.668 & -4.881 & 0.951 & 3.471 \\
b3 & 2.000 & 5.000 & -0.650 & -4.750 & 1.079 & 3.939 \\
b5 & 3.000 & 5.000 & 1.083 & 7.907 & 0.126 & 0.460 \\
Multivariate & & & & & 8.148 & 6.493 \\
\hline
\end{tabular}

The measurement model of the teaching strategies showed that the findings from the research failed to support the hypothesized relationship between the second-order construct and the first-order construct. The results indicated that the final modified CFA model consists of two 1st-order constructs - 'acquiring knowledge' and 'applying and reflection on knowledge'. So, two items are meant to assess teaching strategies promoting LOTs, and five items could be used to assess teaching strategies concerning HOTs. An example of items for the first construct are (b3: to increase students' interest in any scenario from the Prophets' Sirah and b5: to ask students' to explain a concept to their peers) whereas the second construct involves (b17: to state the problem and ask students to find solutions and b22: to encourage students to solve problems referring to selected hadiths). In order to identify the most popular strategy among teachers which focuses on the Islamic education subject, the item frequency and percentage was computed for each construct as in Table 5. The data collected indicated that the most popular strategies used are strategies for 'acquiring knowledge', which focuses more on memorizing basic concepts. And, the least used strategies are strategies for 'applying knowledge and reflection on knowledge' such as problem solving. The second strategy is meant to promote HOTs in students.

Table 4. The CFA results reporting for the measurement model

\begin{tabular}{|c|c|c|c|c|c|}
\hline $2^{\text {nd }}$ order factor & $1^{\text {st }}$ order factor & $\begin{array}{c}\text { Standardized Factor } \\
\text { Loading }\end{array}$ & & & \\
\hline \multirow[t]{2}{*}{ TS } & $\mathrm{AK}$ & 0.956 & & & \\
\hline & AR & 0.975 & & & \\
\hline $1^{\text {st }}$ order factor & Item & $\begin{array}{c}\text { Standardized Factor } \\
\text { loading }(>0.5)\end{array}$ & $\begin{array}{l}\text { CR Alpha } \\
(>0.7)\end{array}$ & $\begin{array}{c}\mathrm{CR} \\
(>0.6)\end{array}$ & $\begin{array}{l}\text { AVE } \\
(>0.5)\end{array}$ \\
\hline \multirow[t]{2}{*}{$\mathrm{AK}$} & b3 & 0.626 & 0.608 & 0.611 & 0.441 \\
\hline & b5 & 0.700 & & & \\
\hline \multirow[t]{5}{*}{$\mathrm{AR}$} & b17 & 0.767 & 0.908 & 0.910 & 0.670 \\
\hline & $\mathrm{b} 22$ & 0.699 & & & \\
\hline & b24 & 0.851 & & & \\
\hline & $\mathrm{b} 25$ & 0.902 & & & \\
\hline & b29 & 0.858 & & & \\
\hline
\end{tabular}

Table 5. Strategies used by teachers

\begin{tabular}{|l|c|c|c|c|}
\hline \multicolumn{1}{|c|}{ Construct } & Mean \pm SD & Range & Skewness & Kurtosis \\
\hline Acquiring Knowledge & $50.22 \pm 5.14$ & 32.00 & 0.41 & 0.23 \\
\hline $\begin{array}{l}\text { Applying and Reflection on } \\
\text { Knowledge }\end{array}$ & $23.33 \pm 6.12$ & 15.00 & 0.22 & 0.11 \\
\hline
\end{tabular}




\section{Conclusion and Implication}

Analysis of validity by CFA and reliability by internal consistency on the data show that the instrument seems to be sound and valid. However, results of the analyses suggest that 11 items are removed from the instrument and only 20 items are retained in the final draft of the instrument. So, it is recommended that further attention be given to the context of programs that comprise HOTs to increase the level of acquisition of it in Islamic education learning, especially through in-service professional development programs for teachers. Teachers can be trained on how to use the strategies by giving students the opportunity to understand the concepts and apply them to daily life situations. The instrument can also be a starting point for further research in different context. Even though the reliability and validity of the final draft of the instrument are within the acceptable range, some of the items have to be removed. So, it would be good if a more detailed analysis with a larger sample (>1000) using Item Response Theory model is used. The use of IRT will allow us to explore deeper into the psychometric characteristics of each item, and thus provide us with a higher level of confidence to keep only important items in the instrument.

\section{Acknowledgement}

The authors would like to express utmost appreciations to the Research Management and Innovation Center (RMIC) for the allocation of the Research Grant University.

\section{References}

Abdullah, A. H., Mokhtar, M., Ali, D.F., Tahir, L.M. \& Kohar, U.H.A. (2017). Mathematics teachers' level of knowledge and practice on the implementation of higher-order thinking skills (HOTS). EURASIA Journal of Mathematics Science and Technology Education, 13(1):3-17.

Anthony, G. \& Walshaw, M. (2009). Effective Pedagogy in Mathematics. Switzerland: International Academy of Education

Anuar Ahmad \& Nelson, J. (2015). Pengaruh kompetensi kemahiran guru dalam pengajaran terhadap pencapaian akademik pelajar dalam mata pelajaran Sejarah. Jurnal Kurikulum \& Pengajaran Asia Pasifik, 3(2), 1-11.

Bahagian Pembangunan Kurikulum (2012). Membudayakan kemahiran berfikir. Kuala Lumpur: Ministry of Education of Malaysia.

Bales, B. L. \& Saffold, F. (2011). A new era in the preparation of teachers for urban schools: Linking multiculturalism, disciplinary-based content and pedagogy. Urban Education, 46(5): 953-974.

Batson, A. D. (1981). Questioning: A Reading/Thinking Foundation for the Gifted.

Ben-David, A., \& Orion, N. (2012). Teachers' voices on integrating metacognition into science education. International Journal of Science Education, 35(18), 1-33.

Caroline L. D. \& Abdul Said Ambotang. (2014). Profesionalisme Guru Novis dalam Pengurusan Pengetahuan, Kesediaan Mengajar dan Kemahiran Berfikir Aras Tinggi (KBAT) Terhadap Pelaksanaan Pengajaran. Seminar Kebangsaan Integriti Keluarga 2014. 11 December, Universiti Malaysia Sabah.

Chapman, J. D., \& Aspin, D. N. (2013). A problem-solving approach to addressing current global challenges in education. British Journal of Educational Studies, 61(1), 49-62. doi: 10.1080/00071005.2012.756166

Clark, D. (2010). Bloom's Taxonomy of Learning Domains: The Three Types of Learning. Retrieved from http://www.nwlink.com/ donclark/hrd/bloom.html

Cope, L. (2014). Task analysis and implementation activities as vehicles for middle school math teacher growth. Delta Journal of Education, 4(2): 11-23.

Diaz, Z., Whitacre, M., Esquierdo, J. J. \& Ruiz-Escalante, J. A. (2013). Why did i ask that question? bilingual/ESL pre-service teachers' insights. International Journal of Instruction, 6(2).

Duncan, D. K., \& Arthurs, L. (2012). Improving student attitudes about learning science and student scientific reasoning skills. Astronomy Education Review, 11(1), 010102-010111.

Forehand, M. (2010). Bloom's Taxonomy. Emerging Perspectives on Learning, Teachin, and Technology. Retrieved from http://projects.coe.uga.edu/epltt/index.php? title= Bloom\%27s_Taxonomy

Forster, M. (2004). Higher order thinking skills. Research Developments, 11(1): 10-15. 
Ganapathy, M. \& Kaur, S. (2014). ESL students' perceptions of the use of Higher Order Thinking Skills in English Language writing. Advances in Language and Literary Studies, 5(5): 81-87.

Georghiades, P. (2004). From the general to the situated: Three decades of metacognition. Research report. International Journal of Science Education, 26(3), 365-383.

Graesser, A. C., McNamara, D. S., \& Van Lehn, K. (2005). Scaffolding deep comprehension strategies through point \& query, auto tutor, and start. Educational Psychologist, 40(4), 225-234.

Gulistan Ahmed, M. A. (2016). Development of a Higher Order Thinking Teaching Models for Basic Education Students in Science, PhD Thesis, University Malaya.

Gulistan M. S., Siraj, S. Nordin, A. B. \& Al-Amedy, O. S. (2015). Higher order thinking skills among secondary school students in science learning. The Malaysian Online Journal of Educational Science, 3(3), 3-20.

Jonathan, L. B., Thiede, K., Strother, S., Bunning, K. \& Peck, D. (2013). Developing mathematical thinking: changing Teachers' knowledge and instruction. Journal of Curriculum and Teaching, 2(2), 62-75.

Kaberman, Z. \& Dori, Y. J. (2009). Metacognition in chemical education: Question posing in the case-based computerized learning environment. Instructional Science, 37(5), 403-436.

Kim, Y. (2005). Cultivating reflective thinking: The effects of a reflective thinking tool on learners' learning performance and metacognitive awareness in the context of on-line learning. (Ph.D. The Pennsylvania State University). Retrieved from http://search.proquest.com/docview/305419245? accountid=28930

Kipnis, M. \& Hofstein, A. (2008). The inquiry laboratory as a source for development of metacognitive skills. International Journal of Science and Mathematics Education, 6(3), 601-627.

Leat, D., \& Lin, M. E. I. (2003). Developing a pedagogy of metacognition and transfer: Some signposts for the generation and use of knowledge and the creation of research partnerships. British Educational Research Journal, 29(3), 383-414.

Ministry of Education Malaysia (2013). Malaysia Education Blueprint 2013-2025 (Preschool to PostSecondary Education). Putrajaya: Kementerian Pendidikan Malaysia.

Miri, B., David, B.-C., \& Uri, Z. (2007). Purposely teaching for the promotion of higher-order thinking skills: A case of critical thinking. Research in Science Education, 37(4), 353-369.

Murray, E. C. (2011). Implementing Higher-Order Thinking In Middle School Mathematics Classrooms. Doctor of Philosophy, Athens, Georgia.

Nelson, B. S. \& Sassi, A. (2000). Shifting Approaches to Supervision: The Case of Mathematics Supervision. Educational Administration Quarterly, 36(4): 553-584.

Nooraini Othman \& Khairul Azmi Mohamad (2014). Thinking skill education and transformational progress in Malaysia. International Education Studies, 7(4): 27-32.

Nurazilawati Abdullah, Abdul Talib Hashim, Rosnidar Mansor, Noraini Mohamed Noh \& Norul Haida Reduzan (2013). Konstruktivisme: Dari Kaca Mata Guru Sains Dan Matematik. International Conference on Social Science Research, ICSSR 2013. 4-5 June. Penang, Malaysia, 1231-1242.

Pappas, E., Pierrakos, O., \& Nagel, R. (2012). Using Bloom's Taxonomy to teach sustainability in multiple contexts. Journal of Cleaner Production. 12(1), 2-3

Peters, E. E., \& Kitsantas, A. (2010). Self-regulation of student epistemic thinking in science: The role of metacognitive prompts. Educational Psychology, 30(1), 27-52.

Rajendran, N. S. (2016). Teaching and Acquiring HOTS, Theory and Practice. Tanjong Malim: Penerbit UPSI.

Rosma Osman, Ong, E.T., Shakinaz Desa \& Wong, K. T. (2012). Tahap kemahiran berfikir dalam kalangan guru sekolah rendah. Journal of Pendidikan Bitara UPSI, 5(1): 1-11.

Şeker, H. \& Kömür, S. (2008). The relationship between critical thinking skills and in-class questioning behaviors of English language teaching students. European journal of teacher education, 31(4), 389402.

Seraphin, K. D., Philippoff, J., Kaupp, L., \& Vallin, L. M. (2012). Metacognition as means to increase the effectiveness of inquiry-based science education. Science Education International, 23(4), 366-382.

Shukla, D. \& Dungsungneon, AJ. (2016). Students' Perceived Level and Teachers' Teaching Strategies of Higher Order Thinking Skills; A Study on Higher Educational Institutions in Thailand, Journal of Education and Practice, 7(12), 211-219.

Stiggins, R. J., Griswold, M. M. \& Wikelund, K. R. (1989). Measuring thinking skills through classroom assessment. Journal of Educational Measurement, 26(3), 233-246.

Supramani, S. (2006). Penyoalan guru: Pemangkin pemikiran aras tinggi murid. Jurnal Pendidikan, 225-246.

Tan, W.C., Baharuddin Aris \& Salleh Abu (2006). GLOTT Model: A pedagogically enriched design framework of learning environment to improve higher order thinking skills. Association for the Advancement of Computing in Education Journal, 14(2), 139-153. 
Tengku Sarina Aini, T. K. \& Faridah, C. H. (2008). Pendekatan individu dalam pengajaran pendidikan Islam sebagai wahana melahirkan modal insan bertamaddun, Jurnal Usuluddin, 27, 141-156.

Thomas, G. P. (2012). Metacognition in science education: Past, present and future considerations. In B. J. Fraser, K. Tobin \& C. J. McRobbie (Eds.), Second international handbook of science education (Vol. 24, pp. 131-144). Dordrecht, The Netherlands: Springer.

Thompson, T. (2008). Mathematics teachers' interpretation of higher-order thinking in bloom's taxonomy. International Electronic Journal of Mathematics Education, 3(2), 96-109.

Van Driel, J. H., \& Berry, A. (2012). Teacher professional development focusing on pedagogical content knowledge. Educational Researcher, 41(1), 26-28.

Veenman, M. V. J. (2011). Learning to self-monitor and self-regulate. In R. E. Mayer \& P. A. Alexander (Eds.), Handbook of research on learning and instruction (197-218). New York, NY: Routledge.

Veenman, M. V. J., Van Hout-Wolters, B. H. A. M., \& Afflerbach, P. (2006). Metacognition and learning: Conceptual and methodological considerations. Metacognition and Learning, 1, 3-14.

Wan Ismail, W. A., Muhammad, W. I, Lubis, M. A. \& Hamzah, M. I. (2016). Kesediaan Guru PI Sekolah Rendah di Selangor, Journal of Advanced Research in Applied Sciences and Engineering Technology. ISSN (online): 2462-1943, Vol. 3 No. 1. Pages 79-92.

Wilson, N. S. \& Bai, H. (2010). The relationships and impact of teachers' metacognitive knowledge and pedagogical understandings of metacognition. Metacognition and Learning, 5(3), 269-288.

Yahya, A. A., Toukal, Z., \& Osman, A. (2012). Bloom's Taxonomy-Based Classification for Item Bank Questions Using Support Vector Machines. In Modern Advances in Intelligent Systems and Tools (pp. 135-140). Berlin, Germany: Springer.

Yee M. H., Jailani Md Yunos, Widad Othman, Razali Hassan, Tee T. K. \& Mimi Mohaffyza Mohamad (2012). The needs analysis of learning higher order thinking skills for generating ideas. Procedia - Social and Behavioral Sciences, 59 (10), 197 - 203.

Zainuddin, A. (2012) A Handbook on SEM Structural Equation Modelling. $6^{\text {th }}$ edn. Kampus Kota Bharu: UiTM Kelantan.

Zohar, A. \& Peled, B. (2008). The effects of explicit teaching of meta-strategic knowledge on low and high achieving students. Learning and Instruction, 18(4), 337-353.

Zohar, A. \& Barzilai, S. (2015). Metacognition and Teaching Higher-Order Thinking in Science Education: Students' Learning, Teachers' Knowledge, and Instructional Practices. In Routledge International Handbook of Research on Teaching Thinking (229-242). 